\title{
Peer Instructor or College Faculty - Who is Better for Leading Teacher Pro- fessional Development? (Evaluation)
}

\section{Mr. Eugene Rutz, University of Cincinnati}

Eugene Rutz is Academic Director in the College of Engineering \& Applied Science at the University of Cincinnati. Responsibilities include oversight of eLearning initiatives, working with high schools on engineering coursework, and academic oversight of the Master of Engineering program. Eugene serves as co-PI on an NSF sponsored math and Science partnership grant.

\section{Dr. Anant R. Kukreti, University of Cincinnati}

ANANT R. KUKRETI, Ph.D., is Director for Engineering Outreach and Professor in the Department of Biomedical, Chemical and Environmental Engineering at the University of Cincinnati (UC), Cincinnati Ohio, USA. He joined UC on 8/15/00 and before that worked 22 years at University of Oklahoma. He teaches structural mechanics, with research in steel structures, seismic analysis and design, and engineering education. He has won five major university teaching awards, two Professorships, two national ASEE teaching awards, and is internationally recognized in his primary research field.

\section{Ms. Julie Steimle, University of Cincinnati}

Julie Steimle received her Bachelor of Arts in English and Secondary Education from Thomas More College. She served as development director and managed academic programs in two non-profit organizations, Pregnancy Care of Cincinnati and the Literacy Network of Greater Cincinnati, before coming to the University of Cincinnati in 2009. Ms. Steimle initially coordinated UC's Supplemental Educational Services Program. Currently, she is the Project Director of the Cincinnati Engineering Enhanced Math and Science Program.

\section{Dr. Catherine Maltbie, University of Cincinnati}

Dr. Cathy Maltbie is a Research Associate at the University of Cincinnati with a joint appointment with the Evaluation Services Center and the Arlitt Child and Family Research and Education Center. She has a BS in Chemical Engineering and a Doctorate in Educational Foundations. Her research areas include evaluation, cognitive and social aspects of educational environments, and STEM education from pre-K through graduate school. 


\section{Peer Instructor or College Faculty - Who is Better for Leading Teacher Professional Development? (Evaluation)}

\section{Program Description}

The University of Cincinnati is beginning its $4^{\text {th }}$ year of an NSF Math and Science Partnership (MSP) Grant. Two of the program's primary goals are:

1. Improve 7-12 science and mathematics achievement to prepare for and increase interest in the college study of engineering or other STEM fields.

2. Develop mathematics and science teacher knowledge of engineering and the engineering design process and challenge-based instruction process through explicit training and classroom implementation support.

In addition to improving math and science teaching, the program also seeks to develop a community of teachers who will implement an explicit and authentic articulation of engineering in 7th-12th grade math and science classrooms so that these teachers will effectively enable students to understand engineering design and consider careers in engineering fields.

The program is targeted to middle school and high school teachers from selected school districts. Approximately 20 teachers take part each year. Engineering design ${ }^{1-2}$ and challenge-based learning ${ }^{3-4}$ are the pedagogical approaches that are at the core of the program. Teachers are recruited from participating districts based on district needs and knowledge of teachers' aptitudes. Teachers complete a formal application process and admission is competitive. The districts participating include urban, rural, suburban and schools with underserved populations.

The primary mechanism for developing this cadre of teachers is through a two-year summer institute $^{5}$. For two summers, teachers complete seven weeks of engineering courses, content courses, and professional development. After successful completion of the two year program, participants earn a Certificate in Engineering Education.

The courses in the program are summarized below.

\section{Core Courses (required):}

- Engineering Foundations: Participating teachers are introduced to the engineering design process, the scope of engineering disciplines, and basic principles of engineering science. Participants then work in teams using the design process to solve open-ended problems.

- Engineering Applications in Math: Participating teachers are introduced to salient math topics presented within the context of their engineering application reinforced through handson laboratory or computer simulation assignments.

- Models and Applications in Physical Sciences: Physical science and lab modules are used to understand the importance of modeling and math in discovering principles of physics and chemistry. 
- Applications of Technology: Various technologies common to engineering are introduced and participating teachers implement the design process on open-ended problems related to those technologies.

Elective Courses (participants choose two):

- Engineering Models: participating teachers connect algebra, trigonometry, and calculus to engineering applications using math fundamental theory and MATLAB programming.

- Engineering Energy Systems: Participants learn about thermodynamics, mass, and energy balances to evaluate energy supply systems and their efficiencies, including renewable energy and nanotechnology.

- Models and Applications in Biological Sciences: Participants learn biology applications by studying statistics in experimental design, pattern seeking in bioinformatics, and modeling in evolution, ecology, and epidemiology through algebra.

- Models and Applications in Earth Systems: Participating teachers learn about the complexity and interaction among natural systems that shape our world.

In the first summer, all participants begin the program by taking the Engineering Foundations course. For the remainder of the first summer, participants take part in an education pedagogy seminar focused on enabling participants to take the experience back into the classroom, the Engineering Applications of Math course and one other course. In the second summer, all participants begin the program by taking the Applications of Technology course. For the remainder of the second summer, participants take part in an education pedagogy seminar and two other courses. All courses seek to illustrate engineering career options and the societal impact of engineering. The pedagogy courses are led by collaborators in the College of Education who have significant experience working with in-service teachers.

\section{Course Instructor Selection and Preparation}

Effective professional development requires providing content and experiences appropriate for adult learners. Felder, et al. ${ }^{6}$ summarizes ideas from Wlodkowski ${ }^{7}$ and others regarding elements of effective professional development. These elements include instructor attributes and pedagogical approaches. For this MSP program these attributes suggested by Wlodkowski are significant:

1. Instructors should be expert in the material being taught

2. Instructors should be knowledgeable about the interests and needs of the students

3. Instructors should have the ability to help students see the relation of the material taught to their professional needs

4. Instructors should model implementation methods and provide opportunities for students to try these methods themselves

Daugherty $^{8}$ and Rutz, et al. ${ }^{9}$ also provide recommendations specific to professional development for teaching engineering design in K-12 settings. These include: modeling approaches and allowing participants to gain hands-on experience with the approach, understanding the context of the participants' educational setting, providing explicit connections between the material taught and the practice of engineering, and including experienced practitioners in leading professional development. 
To identify instructors who exhibited the attributes needed, experienced faculty with reputations as excellent educators were contacted and interviewed to determine whether they had experience working with K-12 educators. Interested faculty members with relevant experience were invited to teach summer institute courses.

In addition to the MSP, the University has a well-established program wherein high schools offer a first year engineering course (Engineering Foundations) to their students ${ }^{10}$. Several teachers in this program have taught and implemented engineering design for a number of years and have led workshops for other high school teachers new to the program. An experienced high school teacher was selected to teach the Engineering Foundations course for the summer institute.

In order to effectively and consistently implement the pedagogical approaches of the MSP, the summer institute courses had to be carefully designed to model and teach the engineering design process, science and math content, and the challenge-based learning pedagogy. It was necessary for the instructors designing and teaching the courses to model the same approach while maintaining a proper emphasis on teaching and learning ${ }^{11}$. Prior to developing their courses, the instructors attended four professional development seminars designed to introduce them to the pedagogical approaches of the program. The purpose of the seminar series was to assure that all of the faculty and staff involved with the project were working in concert toward common goals and using a common perspective. The topics for these seminars were:

1. Program Vision, Goals, and Structure

2. Deconstructing Challenge-Based Learning (engineering design is included)

3. Instructional Approaches and Connecting Academic Content to Design Projects

4. Sharing Course Plans

The seminars were spread out over three months, February to April, during which time the university instructors were also developing their course materials. Each of the seminars included activities, discussion, and assignments that helped the instructors develop their courses.

\section{Program Evaluation}

The MSP courses were first taught in the summer of 2012 and subsequently in 2013 and 2014. A cohort of approximately 20 high school and middle school teachers starts the program each year. These teachers have a variety of backgrounds but all teach science or mathematics. Details of program implementation have been described by Kukreti, et al. ${ }^{5}$

A variety of assessments are conducted as part of the program evaluation. One assessment asked participants to provide feedback to measure the efficacy of the program and to determine if changes could be made to improve the program. Table 1 provides select questions from the survey used at the conclusion of each summer institute (the full survey is provided in Appendix A). Responses are provided using a Likert scale with 1 indicating strongly disagree and 4 strongly agree. In addition, participants completed open-ended responses to these prompts:

- Please indicate what you like most about the course and provide examples.

- Please indicate what aspect of the course you would recommend changing and provide examples. 
Table 1 Participant Evaluation of Summer Courses - Select Questions

Q1. The course helped broaden my understanding of the content.

Q2. The course provided me with ideas and examples illustrating how engineering applications use math and science knowledge, which I can use in my class.

Q3. The course helped me understand the engineering-design process

Q4. The course activities or projects will help me apply the engineering-design process in my teaching.

Q5. The course helped me understand how math and science knowledge is used by engineers to solve societal problems.

Q6. The instructor presented the concepts effectively.

Q7. I would recommend other science or mathematics teachers take this course.

Based on participant feedback, instructors have been replaced and / or the format of a course modified in order to improve the participants' learning experience. The Engineering Applications of Math course provided the greatest number of challenges, in part because of the significant variations in background and aptitude of the participants toward mathematics. In year one, the course was taught by a university faculty; in the second year, two university faculty shared instruction; in year three a university faculty and a high school mathematics instructor with experience in teaching engineering design each taught a distinct section of the course.

\section{Assessment Results}

Data from the end of summer surveys was used to provide a measure of the relative effectiveness of the instructors in the program. Responses to questions from Table 1 were used as a measure of the instructors' effectiveness at enabling the participants to meet the program goals, particularly as they relate to engineering and the engineering design process:

- Improve science and mathematics achievement to increase interest in the college study of engineering or other STEM careers. Q1 and Q2.

- Develop teacher knowledge of engineering and the engineering design process through explicit training and classroom implementation support. Q3 and Q4.

- Develop a community of teachers who will implement an explicit and authentic articulation of engineering in their classrooms. Q5

In addition, as measures of overall effectiveness, Questions 6 and 7 have been included in the analysis.

In the summers of 2012 and 2013, all courses except Engineering Foundations were taught by university faculty; Engineering Foundations was taught by a high school teacher with significant K-12 engineering experience. In the summer of 2014, Engineering Foundations and one section of Engineering Applications of Math were taught by high school teachers with significant K-12 engineering experience; the remaining courses were taught by university faculty.

The mean and standard deviations of participant responses for each of the questions are indicated for programs conducted in the summer of 2012, the summer of 2013 and the summer of 2014. 
Table 2 shows responses for the Engineering Foundations course and for all other courses taught by university faculty. Responses are based on a modified Likert scale with 1 indicting strongly disagreeing and 4 indicating strongly agreeing.

Table 2 Participant Response to End of Program Survey Questions (Mean / Std. Dev.)

\begin{tabular}{|l|c|c|c|c|c|c|}
\hline & \multicolumn{2}{|c|}{2012} & \multicolumn{2}{c|}{2013} & \multicolumn{2}{c|}{2014} \\
\hline Question & $\begin{array}{c}\text { Eng Fnd } \\
\mathrm{n}=16\end{array}$ & $\begin{array}{c}\text { All other } \\
\text { courses } \\
\mathrm{n}=54\end{array}$ & $\begin{array}{c}\text { Eng Fnd } \\
\mathrm{n}=21\end{array}$ & $\begin{array}{c}\text { All other } \\
\text { course } \\
\mathrm{n}=97\end{array}$ & $\begin{array}{c}\text { Eng Fnd } \\
\mathrm{n}=19\end{array}$ & $\begin{array}{c}\text { All other } \\
\text { courses } \mathrm{n}=103\end{array}$ \\
\hline $\begin{array}{l}\text { Understand } \\
\text { content }\end{array}$ & $3.90 / 0.342$ & $3.62 / 0.572$ & $3.74 / 0.577$ & $3.50 / 0.871$ & $3.78 / 0.422$ & $3.30 / 0.737$ \\
\hline $\begin{array}{l}\text { Use math \& } \\
\text { science }\end{array}$ & $3.85 / 0.403$ & $3.27 / 0.94$ & $3.66 / 0.926$ & $3.38 / 1.013$ & $3.78 / 0.422$ & $3.22 / 0.890$ \\
\hline $\begin{array}{l}\text { Understand } \\
\text { design process }\end{array}$ & $3.95 / 0.250$ & $2.66 / 1.26$ & $3.62 / 0.602$ & $3.32 / 1.024$ & $3.86 / 0.351$ & $2.88 / 1.023$ \\
\hline $\begin{array}{l}\text { Apply design } \\
\text { process }\end{array}$ & $4.00 / 0.0$ & $2.94 / 1.08$ & $3.74 / 0.483$ & $3.25 / 1.150$ & $3.86 / 0.351$ & $2.84 / 1.038$ \\
\hline Societal problems & $3.80 / 0.577$ & $3.17 / 1.037$ & $3.62 / 0.680$ & $3.48 / 0.804$ & $3.64 / 0.543$ & $3.42 / 0.727$ \\
\hline $\begin{array}{l}\text { Effective } \\
\text { instructor }\end{array}$ & $3.90 / 0.342$ & $3.57 / 0.830$ & $3.92 / 0.301$ & $3.28 / 1.094$ & $3.97 / 0.169$ & $3.13 / 0.913$ \\
\hline $\begin{array}{l}\text { Recommend } \\
\text { instructor }\end{array}$ & $3.95 / 0.250$ & $3.13 / 1.240$ & $3.96 / 0.218$ & $3.35 / 1.13$ & $3.97 / 0.167$ & $3.06 / 0.986$ \\
\hline
\end{tabular}

Table 3 provides the responses for the two sections of Engineering Applications of Math for the 2014 program. Section 1 is the high school instructor; section 2 university faculty.

Table 3 Participant Response to End of Program Survey Questions for 2014 Math Courses (Mean / Std. Dev.)

\begin{tabular}{|c|c|c|}
\hline Question & Math Section $1 \mathrm{n}=17$ & Math Section $2 \mathrm{n}=8$ \\
\hline Understand content & $3.76 / 0.437$ & $3.25 / 1.035$ \\
\hline Use math \& science & $3.88 / 0.332$ & $3.50 / 0.756$ \\
\hline Understand design process & $3.82 / 0.393$ & $3.50 / 0.535$ \\
\hline Apply design process & $3.88 / 0.332$ & $3.38 / 1.061$ \\
\hline Societal problems & $3.71 / 0.588$ & $3.63 / 0.518$ \\
\hline Effective instructor & $4.00 / 0$ & $3.50 / 0.756$ \\
\hline Recommend instructor & $4.00 / 0$ & $3.50 / 0.756$ \\
\hline
\end{tabular}

While it is included in every course in the program, the engineering design approach is most rigorously included in two courses, Engineering Foundations taught at the start of the first year of the summer institute and Applications of Technology taught at the start of the second year. An analysis of these two courses provides the most direct comparison on how well this approach was implemented by the instructors. Table 4 lists the means and standard deviations of survey questions for these two courses. 
Table 4 Participant Response to End of Program Survey Questions for Engineering Foundations and Applications of Technology Courses (Mean / Std. Dev.)

\begin{tabular}{|c|c|c|c|c|}
\hline & \multicolumn{2}{|c|}{2013} & \multicolumn{2}{c|}{2014} \\
\hline Question & Eng Fnd n=21 & Appl Tech n=13 & Eng Fnd n=19 & $\begin{array}{c}\text { Appl Tech } \\
\mathrm{n}=19\end{array}$ \\
\hline Understand content & $3.74 / 0.577$ & $3.82 / 0.439$ & $3.78 / 0.422$ & $3.11 / 0.809$ \\
\hline Use math \& science & $3.66 / 0.926$ & $3.63 / 0.877$ & $3.78 / 0.422$ & $3.32 / 0.749$ \\
\hline Understand design process & $3.62 / 0.602$ & $3.66 / 0.776$ & $3.86 / 0.351$ & $3.10 / 0.788$ \\
\hline Apply design process & $3.74 / 0.483$ & $3.66 / 0.877$ & $3.86 / 0.351$ & $3.25 / 0.716$ \\
\hline Societal problems & $3.62 / 0.680$ & $3.94 / 0.277$ & $3.64 / 0.543$ & $3.26 / 0.733$ \\
\hline Effective instructor & $3.92 / 0.301$ & $3.75 / 0.630$ & $3.97 / 0.169$ & $3.00 / 0.725$ \\
\hline Recommend instructor & $3.96 / 0.218$ & $3.70 / 0.650$ & $3.97 / 0.167$ & $3.15 / 0.813$ \\
\hline
\end{tabular}

Participants also provided numerous open-ended responses regarding aspects of the courses. While no detailed analysis of these comments has yet been conducted, certain themes are evident based on these comments. Major themes that address the scope of this paper are identified in Table 5.

Table 5 Themes Evident in Open-Ended Responses

- Hands-on activities based on engineering design and challenge-based learning allow participants the best opportunity to learn and develop skills necessary to implement engineering approaches in their classrooms.

- When instructors modeled proper approaches in these activities, participants were best able to learn and implement the approaches themselves.

- Most instructors provided some level of modeling.

- High school instructors clearly provided the most relevant / best modeling of implementation

\section{Analysis of Data}

Analysis was performed to determine if there were statistically significant differences between participant evaluations of courses led by university faculty as compared to courses taught by high school instructors.

Tables 6 - 8 present the results of a one-way ANOVA of the participant responses for the instructor of the Engineering Foundations course as compared with all other courses taught by university faculty. The analysis determines the likelihood that there is a statistically significant difference between the means of the groups being compared for each specific question. In each case there are two groups being compared and the number of responses is given by the "within group" degrees of freedom (df). Results for which the probability of making a type I error (saying these courses have different means compared to each other when they really are not) was less than $5 \%$ and $10 \%$ are indicated by bold text. A 5\% type I error level leads to a $95 \%$ 
confidence that these differences are real and a $10 \%$ type I error leads to a $90 \%$ confidence in these differences.

Table 6 ANOVA for 2012 Program

\begin{tabular}{|c|c|c|c|c|c|}
\hline & & Sum of Squares & df & Mean Square & $\mathrm{F}$ \\
\hline \multirow{2}{*}{ Understand content } & Between Groups & 1.587 & 1 & 1.587 & \multirow{2}{*}{$5.631 *$} \\
\hline & Within Groups & 19.732 & 70 & 0.282 & \\
\hline \multirow{2}{*}{ Use math \& science } & Between Groups & 6.509 & 1 & 6.509 & \multirow{2}{*}{$8.935 *$} \\
\hline & Within Groups & 50.991 & 70 & 0.728 & \\
\hline \multirow{2}{*}{$\begin{array}{l}\text { Understand design } \\
\text { process }\end{array}$} & Between Groups & 31.341 & 1 & 31.341 & \multirow{2}{*}{$25.379 *$} \\
\hline & Within Groups & 80.271 & 65 & 1.235 & \\
\hline \multirow{2}{*}{$\begin{array}{l}\text { Apply design } \\
\text { process }\end{array}$} & Between Groups & 21.543 & 1 & 21.543 & \multirow{2}{*}{ 23.920* } \\
\hline & Within Groups & 59.442 & 66 & 0.901 & \\
\hline \multirow{2}{*}{ Societal problems } & Between Groups & 7.626 & 1 & 7.626 & \multirow{2}{*}{ 8.387* } \\
\hline & Within Groups & 60.925 & 67 & 0.909 & \\
\hline \multirow{2}{*}{ Effective instructor } & Between Groups & 2.099 & 1 & 2.099 & \multirow{2}{*}{$3.703 * *$} \\
\hline & Within Groups & 39.679 & 70 & 0.567 & \\
\hline \multirow{2}{*}{$\begin{array}{l}\text { Recommend } \\
\text { instructor }\end{array}$} & Between Groups & 13.120 & 1 & 13.120 & \multirow{2}{*}{$10.743 *$} \\
\hline & Within Groups & 85.491 & 70 & 1.221 & \\
\hline
\end{tabular}

$* 95 \%$ confidence level

** $90 \%$ confidence level

Table 7 ANOVA for 2013 Program

\begin{tabular}{|c|c|c|c|c|c|}
\hline & & Sum of Squares & df & Mean Square & $\mathrm{F}$ \\
\hline \multirow{2}{*}{ Understand content } & Between Groups & 1.404 & 1 & 1.404 & \multirow{2}{*}{2.048} \\
\hline & Within Groups & 79.553 & 116 & .686 & \\
\hline \multirow{2}{*}{ Use math \& science } & Between Groups & 2.175 & 1 & 2.175 & \multirow{2}{*}{2.182} \\
\hline & Within Groups & 115.596 & 116 & .997 & \\
\hline \multirow{2}{*}{$\begin{array}{l}\text { Understand design } \\
\text { process }\end{array}$} & Between Groups & 2.353 & 1 & 2.353 & \multirow{2}{*}{2.529} \\
\hline & Within Groups & 107.919 & 116 & .930 & \\
\hline \multirow{2}{*}{$\begin{array}{l}\text { Apply design } \\
\text { process }\end{array}$} & Between Groups & 6.290 & 1 & 6.290 & \multirow{2}{*}{$5.551 *$} \\
\hline & Within Groups & 130.292 & 115 & 1.133 & \\
\hline \multirow{2}{*}{ Societal problems } & Between Groups & .518 & 1 & .518 & \multirow{2}{*}{0.843} \\
\hline & Within Groups & 71.321 & 116 & .615 & \\
\hline \multirow{2}{*}{ Effective instructor } & Between Groups & 11.094 & 1 & 11.094 & \multirow{2}{*}{$11.020 *$} \\
\hline & Within Groups & 116.779 & 116 & 1.007 & \\
\hline \multirow{2}{*}{$\begin{array}{l}\text { Recommend } \\
\text { instructor }\end{array}$} & Between Groups & 10.151 & 1 & 10.151 & \multirow{2}{*}{$9.525 *$} \\
\hline & Within Groups & 123.612 & 116 & 1.066 & \\
\hline
\end{tabular}

* $95 \%$ confidence level 
Table 8 ANOVA for 2014 Program

\begin{tabular}{|c|c|c|c|c|c|}
\hline & & Sum of Squares & $\mathrm{df}$ & Mean Square & $\mathrm{F}$ \\
\hline \multirow[t]{2}{*}{ Understand content } & Between Groups & 2.707 & 1 & 2.707 & \multirow{2}{*}{$5.865 *$} \\
\hline & Within Groups & 55.381 & 120 & 0.462 & \\
\hline \multirow{2}{*}{ Use math \& science } & Between Groups & 2.090 & 1 & 24.210 & \multirow{2}{*}{$3.144 * *$} \\
\hline & Within Groups & 81.096 & 122 & 2.090 & \\
\hline \multirow{2}{*}{$\begin{array}{l}\text { Understand design } \\
\text { process }\end{array}$} & Between Groups & 11.694 & 1 & 11.694 & \multirow{2}{*}{$13.315^{*}$} \\
\hline & Within Groups & 103.631 & 118 & 0.878 & \\
\hline \multirow{2}{*}{$\begin{array}{l}\text { Apply design } \\
\text { process }\end{array}$} & Between Groups & 11.153 & 1 & 11.153 & \multirow{2}{*}{$11.986^{*}$} \\
\hline & Within Groups & 113.517 & 122 & 0.930 & \\
\hline \multirow{2}{*}{ Societal problems } & Between Groups & 0.205 & 1 & 0.205 & \multirow{2}{*}{0.436} \\
\hline & Within Groups & 56.263 & 120 & 0.469 & \\
\hline \multirow{2}{*}{ Effective instructor } & Between Groups & 6.996 & 1 & 6.996 & \multirow{2}{*}{$10.065^{*}$} \\
\hline & Within Groups & 83.406 & 120 & 0.695 & \\
\hline \multirow{2}{*}{$\begin{array}{l}\text { Recommend } \\
\text { instructor }\end{array}$} & Between Groups & 8.637 & 1 & 8.637 & \multirow{2}{*}{$10.768 *$} \\
\hline & Within Groups & 96.248 & 120 & 0.802 & \\
\hline
\end{tabular}

* 95\% confidence level

$* * 90 \%$ confidence level

Table 9 presents the results of a one-way ANOVA of participant responses for 2014 for the Engineering Applications of Math section taught by a university faculty to that section taught by a high school instructor. Statistically significant results are indicated by bold highlighting at both the $95 \%$ confidence level and $90 \%$ confidence level.

Table 9 ANOVA for 2014 Math Courses

\begin{tabular}{|c|c|c|c|c|c|}
\hline & & Sum of Squares & $\mathrm{df}$ & Mean Square & $\mathrm{F}$ \\
\hline \multirow[t]{2}{*}{ Understand content } & Between Groups & 1.441 & 1 & 1.441 & \multirow{2}{*}{$3.139 * *$} \\
\hline & Within Groups & 10.559 & 23 & 0.459 & \\
\hline \multirow{2}{*}{ Use math \& science } & Between Groups & 0.795 & 1 & 0.795 & \multirow{2}{*}{$3.173 * *$} \\
\hline & Within Groups & 5.765 & 23 & 0.251 & \\
\hline \multirow{2}{*}{$\begin{array}{l}\text { Understand design } \\
\text { process }\end{array}$} & Between Groups & 0.569 & 1 & 0.569 & \multirow{2}{*}{$2.929 * *$} \\
\hline & Within Groups & 4.471 & 23 & 0.194 & \\
\hline \multirow{2}{*}{$\begin{array}{l}\text { Apply design } \\
\text { process }\end{array}$} & Between Groups & 1.400 & 1 & 1.400 & \multirow{2}{*}{$3.341 * *$} \\
\hline & Within Groups & 9.640 & 23 & 0.419 & \\
\hline \multirow{2}{*}{ Societal problems } & Between Groups & 0.036 & 1 & 0.036 & \multirow{2}{*}{0.111} \\
\hline & Within Groups & 7.404 & 23 & 0.322 & \\
\hline \multirow{2}{*}{ Effective instructor } & Between Groups & 1.360 & 1 & 1.360 & \multirow{2}{*}{ 7.820* } \\
\hline & Within Groups & 4.000 & 23 & 0.174 & \\
\hline \multirow{2}{*}{$\begin{array}{l}\text { Recommend } \\
\text { instructor }\end{array}$} & Between Groups & 1.360 & 1 & 1.360 & \multirow{2}{*}{$7.820 *$} \\
\hline & Within Groups & 4.00 & 23 & 0.174 & \\
\hline
\end{tabular}

$* 95 \%$ confidence level

** $90 \%$ confidence level 
An independent sample t-test ( 2 sided) was used to compare the data regarding Engineering Foundations and Applications of Technology from Table 4. Results of that analysis are provided in Table 10. Statistically significant results are indicated by bold text.

Table 10 t- Test Results Engineering Foundations and Applications of Technology

\begin{tabular}{|l|c|c|c|c|c|c|}
\hline & \multicolumn{3}{|c|}{2013} & \multicolumn{3}{c|}{2014} \\
\hline & $\mathrm{t}$ & $\mathrm{df}$ & Sig. & $\mathrm{t}$ & $\mathrm{df}$ & Sig. \\
\hline Understand content & -0.549 & 32 & 0.587 & $\mathbf{3 . 2 7 3}^{*}$ & 36 & 0.002 \\
\hline Use math \& science & 0.262 & 32 & 0.795 & $\mathbf{3 . 1 0 4}^{*}$ & 36 & 0.004 \\
\hline $\begin{array}{l}\text { Understand design } \\
\text { process }\end{array}$ & 0.596 & 32 & 0.556 & $\mathbf{3 . 7 2 3}^{*}$ & 37 & 0.001 \\
\hline $\begin{array}{l}\text { Apply design } \\
\text { process }\end{array}$ & 0.103 & 32 & 0.919 & $\mathbf{2 . 2 1 5}^{*}$ & 37 & 0.033 \\
\hline Societal problems & $\mathbf{- 2 . 0 0 8} *$ & 32 & 0.053 & 1.543 & 36 & 0.131 \\
\hline Effective instructor & 1.328 & 32 & 0.194 & $\mathbf{5 . 2 7 2}^{*}$ & 36 & 0.000 \\
\hline $\begin{array}{l}\text { Recommend } \\
\text { instructor }\end{array}$ & $\mathbf{2 . 2 0 0 *}$ & 32 & 0.035 & $\mathbf{4 . 1 2 1}^{*}$ & 37 & 0.000 \\
\hline
\end{tabular}

* $95 \%$ confidence level

\section{Discussion of Results}

All instructors were carefully selected and then trained in the pedagogical approaches (engineering design-based learning and challenge-based learning) that were central to the program. The survey data (Tables 2 - 4) indicates that all instructors were effective; responses validate that participants were able to learn and apply concepts. The analysis does demonstrate, however, that there are statistically significant differences in participants' evaluation of instructor effectiveness, and by extension, meeting the goals of the program.

Regarding the first goal, "improve science and mathematics achievement to increase interest in the college study of engineering or other STEM careers," results from Tables 6-8 indicate that for 2012 and 2014 (however not for 2013) there were statistically significant differences noted in participants' responses. Participants indicated that the high school instructors were more effective at enabling participants to meet this objective. Data in Table 9 also supports this conclusion. Data in Table 10 supports this conclusion for 2014 but not 2013.

Regarding the second goal, "develop teacher knowledge of engineering and the engineering design process through explicit training and classroom implementation support," results from Tables 6-8 indicate that for each year there were statistically significant differences noted in participants' responses. Participants indicated that the high school instructors were more effective at enabling participants to meet this objective. Data in Table 9 also supports this conclusion. Data in Table 10 supports this conclusion for 2014 but not 2013.

Regarding the third goal, "develop a community of teachers who will implement an explicit and authentic articulation of engineering in their classrooms," results from Tables 6-8 indicate that for 2012 only there were statistically significant differences noted in participants' responses. The data indicates that the high school instructor was more effective at enabling participants to 
meet this objective. Data in Table 9 did not indicate any statistically significant differences. Data in Table 10 indicates the faculty member was more effective in 2013 but there were no significant differences for 2014.

Regarding general measures of instructor effectiveness, results from Tables 6-8 indicate that for each year there were statistically significant differences noted in participants' responses.

Participants indicated that the high school instructors were viewed more positively than faculty. Data in Table 9 also supports this conclusion. Data in Table 10 supports this conclusion for both 2013 and 2014.

In comparing participants' evaluation of instructor effectiveness it is clear that for the explicit goals of the program (improve science and math teaching; develop teacher knowledge) the high school instructors who taught in this program were ranked as more effective than the university faculty who taught in this program. No real distinction can be drawn as regards "developing a community of teachers..." For general measures of teacher effectiveness, the high school instructors were clearly considered to be more effective than university faculty.

While faculty clearly have deeper engineering and science content knowledge than the high school instructors, the "master" high school instructors are more knowledgeable about the context of the K-12 educational system and have much greater experience in the settings of the participants as compared to the faculty. This experience with the context of the educational setting provides competencies that most faculty do not have. These results are consistent with those of Guskey ${ }^{12}$, who concludes that this understanding of context is more significant than content knowledge or the particular process used to deliver professional development. These findings are also consistent with the general conclusions of professional development described by the $\mathrm{NAE}^{13}$ and others ${ }^{9}$.

The themes expressed in Table 5 suggest an additional competency that the experienced high school instructors exhibit to a greater extent than university faculty. High school teachers leading the professional development were viewed as more effective at modeling the pedagogies as compared to the university faculty. Wlodkowski ${ }^{7}$ and Borphy, et al. ${ }^{13}$ both emphasize the need for teachers to have appropriate modeling of teaching methods. Custer \& Daugherty ${ }^{11}$ indicate that this modeling must also be flexible enough to meet the diverse needs represented by the participants of the professional development program. Both the context and modeling competencies are discussed by Penuel, et al. ${ }^{15}$ They suggest that this modeling is best performed when an understanding of the local context is considered. We conclude that experienced high school teachers, particularly ones who have led other professional development programs, are able to provide this modeling using language and examples that are more suited to their peers as compared with university faculty.

\section{Conclusions}

The professional development program is effective at enabling the MSP program to meet its goals. Instructor preparation and experiences allow participants to broaden content knowledge and develop competencies in the pedagogies used in the program. The professional development enables the participants to gain new knowledge and implement engineering design and challenge based learning with their own students. 
While the number of participants is large enough to make statistically-based inferences about their experiences, there is not enough data to draw general conclusions regarding differences between high school instructors and university faculty. In 2012 and 2013 there was one course taught by a high school instructor and multiple (4-6) courses taught by university faculty. In 2014 there were two courses taught by high school instructors. For instructors teaching in this program, the high school instructors with experience at implementing engineering design in the K-12 setting are viewed as more effective than university faculty at leading professional development for K-12 educators.

It is important to not generalize these results to all programs. We can only conclude that for K12 professional development programs, experienced high school instructors should receive equal consideration for leading these programs. Two primary factors that suggest consideration of experienced high school instructors are: 1) high school instructors have a much better understanding of the context of the K-12 setting than faculty, and 2) their experience in the K-12 setting enables high school instructors to more effectively model the pedagogies than most faculty.

One general conclusion based on this study is that there is an order to the program attributes described by Wlodkowski. ${ }^{7}$ Based on the findings from this program we suggest this order of significance:

1. Instructors should be knowledgeable about the interests and needs of the students

2. Instructors should model implementation methods and provide opportunities for students to try these methods themselves

3. Instructors should have the ability to help students see the relation of the material taught to their professional needs

4. Instructors should be expert in the material being taught

The specific goals of any professional development program must be considered along with available personnel resources when selecting appropriate instructors. Professional development programs designed to bring engineering to K-12 settings should seek to utilize experienced K-12 educators to the extent possible to lead the professional development.

\section{References}

1. Dym, C. L., Agogino, A. M., Eris, O., Frey, D. D., and Leifer, L. J. (2005), Engineering Design Thinking, Teaching, and Learning. Journal of Engineering Education, 94: 103-120. doi: 10.1002/j.21689830.2005.tb00832.x

2. Silk, E. M., Schunn, C. D., and Cary, M. S. (2009), The Impact of an Engineering Design Curriculum on Science Reasoning in an Urban Setting. J Sci Educ Technol (2009) 18:209-223 doi: 10.1007/s10956-0099144-8

3. Apple. (2010), Challenge Based Learning A Classroom Guide. Available at https://www.apple.com/education/docs/CBL_Classroom_Guide_Jan_2011.pdf Accessed on 01/09/15. 
4. Educause. (2012), 7 Things You Should Know About Challenge-Based Learning. Available at https://net.educause.edu/ir/library/pdf/ELI7080.pdf. Accessed on 01/07/15.

5. Kukreti, A. R., Rutz, E. E., Steimle, J., Jackson, H. E., and Maltbie, C. (2013), Training Secondary Math and Science Teachers to Bring an Engineering Perspective to the Classroom. Proceedings of the ASEE Annual Conference and Exhibition. Atlanta, GA.

6. Felder, R. M., Brent, R., and Prince, M. J. (2011), Engineering Instructional Development: Programs, Best Practices, and Recommendations. Journal of Engineering Education, 100(1), 89 - 122.

7. Wlodkowski, R. J. (1999), Enhancing Adult Motivation to Learn: A Comprehensive Guide for Teaching All Adults. $2^{\text {nd }}$ ed. New York: John Wiley and Sons.

8. Daugherty, J. L. (2012), Infusing Engineering Concepts: Teaching Engineering Design. Available at http://files.eric.ed.gov/fulltext/ED537384.pdf. Accessed 01/09/15

9. Rutz, E., Kukreti, A., and Maltbie, C. (2012), Teachers Make Lousy Students, and What You Can Do About It. Proceedings of the ASEE Annual Conference and Exhibition. San Antonio, TX.

10. Rutz, E. (2011), Using the Engineering Design Process to Develop and Implement a High School Introduction to Engineering Course. Proceedings of the ASEE Annual Conference and Exhibition. Vancouver, B.C. Canada.

11. Custer, R. L., and Daugherty, J. L. (2009-1), The Nature and Status of STEM Professional Development. Effective Practices for Secondary Level Engineering Education. Available at http://digitalcommons.usu.edu/ncete_cstudies/11/. Accessed 1/09/15.

12. Guskey, T. R. (2009), Closing the Knowledge Gap on Effective Professional Development. Educational Horizons, v87, n4, p 224-233.

13. Custer, R. L. and Daugherty, J. L. (2009-2), Professional Development for Teachers of Engineering: Research and Related Activities. The Bridge. National Academy of Engineering. Fall 2009, pgs 18-24.

14. Borphy, S., Klein, S., Portsmore, M, and Rogers, C. (2008), Advancing Engineering Education in P-12 Classrooms. Journal of Engineering Education, 97: 369-387. doi: 10.1002/j.2168-9830.2008.tb00985.x

15. Penuel, R. P., Fishman, B. J., Yamaguchi, R. and Gallagher, L. P. (2007), What Makes Professional Development Effective? Strategies That Foster Curriculum Implementation. American Educational Research Journal, Vol. 44, No. 4, pp. 921 -958. doi: 10.3102/0002831207308221 


\section{Appendix A Full Survey}

1. The course helped broaden my understanding of the content.

2. The course activities or projects were an effective means to learn the concepts.

3. The course helped me understand challenge-based learning through the use of a design challenge.

4. The course activities or projects will help me apply challenge-based learning to my teaching.

5. The course helped me understand the engineering-design process.

6. The course activities or projects will help me apply the engineering-design process in my teaching.

7. The course provided me with ideas and examples illustrating how engineering applications use math and science knowledge, which I can use in my class.

8. The course helped me understand how math and science knowledge leads to different STEM career choices.

9. The course helped me understand how math and science knowledge is used by engineers to solve societal problems.

10. The course provided opportunities to enhance my oral communication skills.

11. The course provided opportunities to enhance my written communication skills.

12. The course activities or projects helped cultivate effective team-work.

13. The students in my school will benefit from my experiences in this course.

14. The instructor presented the concepts effectively.

15. The sessions allowed for questions, answers, and discussions.

16. The course materials were well organized.

17. The course materials supported the concepts taught.

18. I would recommend other science or mathematics teachers take this course. 